\title{
STUDY OF CALVING PATTERN IN DAIRY COWS
}

\author{
V. V. Potdar*, Y. S. GaundareJ. R. Khadse, Sachin Joshi, Marimuthu Swaminathan and A.B.Pande \\ Central Research Station, BAIF Development Research Foundation \\ https://doi.org/10.35410/IJAEB.2020.5488
}

\begin{abstract}
The present study was conducted with an aim to access the different calving pattern in cross bred cows of different zones in Uttar Pradesh state. A total of 8755 calving records of cross bred dairy cows were screened retrospectively for peri-parturient reproductive disorders These calvings were from animals which were inseminated at cattle development centres in Uttar Pradesh run by BAIF Development Research Foundation during year 2010 to 2015.. The most common reproductive problems recorded in the present study were Out of total 8755 highest number 3900 (90.2\%) normal calving were reported in central plain zone of Uttar Pradesh. Highest number 1140 (30.6\%) of minor assistance was reported from Mid-Western plain zone of Uttar Pradesh. Highest number of dystocia cases 68 (9.6\%) and 45 (6.4\%) number of caesarian cases were reported from Western plain zone of Uttar Pradesh. Highest number of abortions 204 $(5.5 \%)$ were reported at Mid -Western plain of Uttar Pradesh. These disorders can be managed by adopting good nutritional and manage mental facilities in the herd. Incidence of abortion was $(5 \%)$ in winter and summer season while it was $(6 \%)$ rainyseason. Highest numbers of calving were recorded in summer season (80\%).In retention of placenta study overall $32.48 \%(2844)$ cases show retention of placenta while in Central plain of Uttar Pradesh it was $22.54 \%$ in Mid Western plain of Uttar Pradesh 36.28\% and in Western plain zone of Uttar Pradesh 73.48\%. In parity wise study of retention of placenta were highest in third parity $39.38 \%$ while lowest in first parity $26.40 \%$ while in heifer it was $33.03 \%$. These disorders can be managed by adopting good nutritional and manage mental facilities in the herd.
\end{abstract}

Keywords: Cattle, calving pattern, Zones, Incidence calving pattern,dystocia, abortion, caesarian.

\section{INTRODUCTION}

Reproductive efficiency is a critical component of a successful dairy programme at farmer level and acts as an important component of a profitable dairy farm, whereas reproductive inefficiency is one of the most costly problems facing the dairy farmers today. Reproductive problems occur frequently in dairy cows and can dramatically affect reproductive efficiency. Among the most common reproductive disorders that have direct impact on reproductive performance of dairy cows such as abortion, stillbirth, metritis and retained placenta; dystocia is the leading disorder that can results in impaired reproductive function. Parturition is a stressful process for cows and their calves. Abortion is the expulsion from the uterus of living foetus before it reaches a viable age or more commonly the expulsion of a dead foetus of recognizable size at any stage of gestation (Roberts, 1971).Abnormal parturition further exacerbates the stress Dystocia or 
Vol. 5, No. 02; 2020

ISSN: $2456-8643$

difficult calving has been along-standing problem in dairy industry. It is a leading factor of calf death at or shortly after birth and also results in uterine infections, retained placenta, andlonger calving intervals. It has been estimated that between 2 and 23\% of cows in a herd experience difficult calving that require farmer or veterinarian assistance. Hence, a study was planned to check calving pattern in dairy cattle of different zones of Uttar Pradesh state.

\section{MATERIAL AND METHODS}

The data of 8755 calving's of dairy cattle inseminated at different Cattle Development Centres of districts of Uttar Pradesh were considered for this study. This Centres were working from June 2010 to May 2015. The available data was classified on the basis of Agro climatic Zone viz. Central plain of Uttar Pradesh (Etah and Unnao), Mid-western plain of Uttar Pradesh (Bareilly) and Western plain zone Uttar Pradesh (Meerut). Parity (Heifer,1,2,3,4,5 \& Above), AI sequence number $(1,2,3)$, heat stage (Early,Mid,Late),body condition (No ribs exposed, One rib exposed, Two ribs exposed, Three ribs exposed),AI year $(2010,2011,2012,2013,2014,2015)$ and season (Rainy,Summer,Winter) and calf sex (Male, female) and retention of placenta study. All observations (calving, minor assistant, caesarean, dystocia and abortion) were noted from artificial insemination of animal till calving or abortion. For collection of information mobile based device was provided to all centre incharge who collect animal wise information and this information was updated at server level to central office. Calculation of calving pattern was divided into Normal Calving, Minor Assistant, Caesarian, Dystocia and Abortion. The influence of various non-genetic factors, viz. Agro climatic Zone, Parity, Year and Season of calving period, Heat Stage and calf sex over incidence of calving pattern was analyzed by using the Chisquare method.

\section{RESULTS AND DISCUSSION}

Three agro climatic zone of Uttar Pradesh were considered for this study. There agro climatic zones were Central plain of Uttar Pradesh covering Etah and Unnao district. Mid -Western plain of Uttar Pradesh covering Bareilly district and Western plain zone of Uttar Pradesh covering Meerut district. Out of total 8755 calving's studied $77.4 \%$ were normal calving while $15.0 \%$ required minor assistance while $0.6 \%$ found to caesarean and 5.2\% got abortion.Agro climatic Zone, Parity, Season of calving, calf sex are having effect of calving while Heat Stage, AI sequence number,year of calving were not having any effect over incidence of calving pattern

\section{Agro Climatic Zone Wise Study of Calving Pattern}

In agro climatic zones of Uttar Pradesh maximum number of normal calvings were observed in central plain zone of Uttar Pradesh. Maximum number of minor assistance was observed in midwestern plain zone of Uttar Pradesh, highest dystocia incidence was observed in western plain zone of Uttar Pradesh 9.6\% while highest abortion was observed in mid-western plain zone of Uttar Pradesh 5.5\%. 
Table .1 Agro climatic Zone Wise Calving Pattern

\begin{tabular}{|l|c|c|c|c|c|c|}
\hline Agro climatic Zone & $\begin{array}{c}\text { Abortio } \\
\mathbf{n}\end{array}$ & $\begin{array}{c}\text { Caesaria } \\
\mathbf{n}\end{array}$ & $\begin{array}{c}\text { Dystoci } \\
\mathbf{a}\end{array}$ & $\begin{array}{c}\text { Minor } \\
\text { Assistance }\end{array}$ & Normal & $\begin{array}{c}\text { Gran } \\
\mathbf{d} \\
\text { Total }\end{array}$ \\
\hline $\begin{array}{l}\text { Central plain of Uttar } \\
\text { Pradesh }\end{array}$ & $\begin{array}{c}221 \\
(5.1 \%)\end{array}$ & $3(0.1 \%)$ & $\begin{array}{c}43(1.0 \% \\
)\end{array}$ & $159(3.7 \%)$ & $\begin{array}{c}3900(90.2 \% \\
)\end{array}$ & 4326 \\
\hline $\begin{array}{l}\text { Mid -Western plain of } \\
\text { Uttar Pradesh }\end{array}$ & $\begin{array}{c}204 \\
(5.5 \%)\end{array}$ & $7(0.2 \%)$ & $\begin{array}{c}47(1.3 \% \\
)\end{array}$ & $\begin{array}{c}1140(30.6 \% \\
)\end{array}$ & $2326(62.5 \%$ & \\
\hline $\begin{array}{l}\text { Western plain zone of } \\
\text { Uttar Pradesh }\end{array}$ & $\begin{array}{c}27 \\
(3.8 \%)\end{array}$ & $45(6.4 \%)$ & $\begin{array}{c}68(9.6 \% \\
)\end{array}$ & $17(2.4 \%)$ & $548(77.7 \%)$ & 705 \\
\hline Grand Total & 452 & 55 & 158 & 1316 & 6774 & 8755 \\
\hline
\end{tabular}

\section{In Parity Wise Study of Calving Pattern}

highest normal calving was observed in second parity $(81.2 \%)$ followed by $5^{\text {th }}$ and above parity $(81.0 \%)$ then in fourth parity (78.9\%) at fourth place in second parity $(76.0 \%)$, in heifers $(75.8 \%)$ and lowest in third parity (75.6\%).Highest minor assistance was observed in third parity (17.4\%) while lowest was in $5^{\text {th }}$ and above parity (11.0\%).Maximum dystocia was observed in heifers (3.0\%) and lowest in second and fifth parity. Maximum cesarian were recorded in second parity $(1.2 \%)$ while lowest recorded in fourth parity. Maximum abortion were recorded in fifth and above parity $(7.0 \%)$ while lowest in first parity $(5.2 \%)$

Table .2 Parity Wise Calving Pattern

\begin{tabular}{|c|c|c|c|c|c|c|}
\hline Lactation Number & Abortion & $\begin{array}{c}\text { Caesaria } \\
n\end{array}$ & Dystocia & $\begin{array}{c}\text { Minor } \\
\text { Assistance }\end{array}$ & Normal & $\begin{array}{c}\text { Grand } \\
\text { Total }\end{array}$ \\
\hline Heifer & $\begin{array}{c}158(5.3 \% \\
)\end{array}$ & $12(0.4 \%)$ & $\begin{array}{c}90(3.0 \% \\
)\end{array}$ & $\begin{array}{c}464(15.5 \% \\
)\end{array}$ & $\begin{array}{c}2264(75.8 \% \\
)\end{array}$ & 2988 \\
\hline 1 & $90(5.2 \%)$ & $8(0.5 \%)$ & $\begin{array}{c}18(1.0 \% \\
)\end{array}$ & $\begin{array}{c}301(17.3 \% \\
)\end{array}$ & $\begin{array}{c}1318(76.0 \% \\
)\end{array}$ & 1735 \\
\hline 2 & $90(4.7 \%)$ & $23(1.2 \%)$ & $\begin{array}{c}26(1.4 \% \\
)\end{array}$ & $\begin{array}{c}220(11.5 \% \\
)\end{array}$ & $\begin{array}{c}1548(81.2 \% \\
)\end{array}$ & 1907 \\
\hline 3 & $59(5.0 \%)$ & $10(0.8 \%)$ & $\begin{array}{c}14(1.2 \% \\
)\end{array}$ & $\begin{array}{c}206(17.4 \% \\
)\end{array}$ & $897(75.6 \%)$ & 1186 \\
\hline 4 & $34(5.3 \%)$ & $2(0.3 \%)$ & $7(1.1 \%)$ & $92(14.4 \%)$ & $504(78.9 \%)$ & 639 \\
\hline $5 \& \mathrm{~A}$ & $21(7.0 \%)$ & $0 \%$ & $3(1.0 \%)$ & $33(11.0 \%)$ & $243(81.0 \%)$ & 300 \\
\hline Grand Total & 452 & 55 & 158 & 1316 & 6774 & 8755 \\
\hline
\end{tabular}

Artificial Insemination Sequence Number Wise Study of Calving Pattern 
In AI sequence study in all sequence normal calving were observed in range of 76 to $78 \%$. Minor assistant was observed in 14 to $16.5 \%$ range. Highest dystocia cases were observed in first sequence $(1.9 \%)$. While in second $(1.6 \%)$ and in third $(0.9 \%)$.Highest cesarian cases were noted in first sequence $(0.8 \%)$. While more than $5.0 \%$ of abortion were observed in all sequence.

Table .3 AI Sequence Wise Calving Pattern

\begin{tabular}{|l|c|c|c|c|c|c|}
\hline $\begin{array}{l}\text { Artificial } \\
\text { Insemination } \\
\text { Sequence } \\
\text { Number }\end{array}$ & Abortion & Caesarian & Dystocia & $\begin{array}{c}\text { Minor } \\
\text { Assistance }\end{array}$ & Normal & $\begin{array}{c}\text { Grand } \\
\text { Total }\end{array}$ \\
\hline 1 & $350(5.2 \%)$ & $51(0.8 \%)$ & $129(1.9 \%)$ & $992(14.7 \%)$ & $5230(77.5 \%)$ & 6752 \\
\hline 2 & $79(5.1 \%)$ & $3(0.2 \%)$ & $25(1.6 \%)$ & $254(16.5 \%)$ & $1183(76.6 \%)$ & 1544 \\
\hline 3 & $23(5.0 \%)$ & $1(0.2 \%)$ & $4(0.9 \%)$ & $70(15.3 \%)$ & $361(78.6 \%)$ & 459 \\
\hline Grand Total & 452 & 55 & 158 & 1316 & 6774 & 8755 \\
\hline
\end{tabular}

\section{In Body Typing Wise Study of Calving Pattern}

Highest percentage of normal calving were observed in animals whose ribs were not exposed $(83.9 \%)$. Highest percentage of minor assistance were observed in animals whose two ribs were exposed (18.5\%). Highest dystocia were noted in animals whose no ribs were exposed (4.5\%). Highest abortion were recorded in animals whose one rib was exposed (5.9\%).

\section{Table . 4 Body Typing Wise Calving Pattern}

\begin{tabular}{|l|c|c|c|c|c|c|}
\hline Body Typing & Abortion & Caesarian & Dystocia & $\begin{array}{c}\text { Minor } \\
\text { Assistance }\end{array}$ & Normal & $\begin{array}{c}\text { Grand } \\
\text { Total }\end{array}$ \\
\hline No ribs exposed & $54(5.2 \%)$ & $6(0.6 \%)$ & $47(4.5 \%)$ & $60(5.8 \%)$ & $868(83.9 \%)$ & 1035 \\
\hline One rib exposed & $87(5.9 \%)$ & $41(2.8 \%)$ & $27(1.8 \%)$ & $195(13.1 \%)$ & $1136(76.4 \%)$ & 1486 \\
\hline Two ribs exposed & $182(5.0 \%)$ & $2(0.1 \%)$ & $45(1.2 \%)$ & $667(18.5 \%)$ & $2711(75.2 \%)$ & 3607 \\
\hline $\begin{array}{l}\text { Three ribs } \\
\text { exposed }\end{array}$ & $129(4.9 \%)$ & $6(0.2 \%)$ & $39(1.5 \%)$ & $394(15.0 \%)$ & $2059(78.4 \%)$ & 2627 \\
\hline Grand Total & 452 & 55 & 158 & 1316 & 6774 & 8755 \\
\hline
\end{tabular}

\section{Heat Stage Wise Study of Calving Pattern}

In heat stage study highest percentage of normal calving's were recorded in late heat stage animals $(81.7 \%)$ followed by mid heat stage $(76.9 \%)$ and $(70.8 \%)$ in early heat stage. Highest minor assistance were recorded in early heat stage (20.5\%) followed by mid heat stage $(15.8 \%)$ and lowest in late heat stage (8.8\%). Highest dystocia were observed in early heat stage (4.2\%) followed by $(1.9 \%)$ in mid heat stage and lowest in late heat stage $(0.8 \%)$. Highest caesarean were recorded in late heat stage $(3.1 \%)$ followed by $(0.2 \%)$ in early heat stage and lowest in mid heat stage $(0.2 \%)$. Highest abortions were recorded in late heat stage $(5.6 \%)$ followed by mid heat stage (5.1\%) and lowest in early heat stage (3.8\%). 
Vol. 5, No. 02; 2020

ISSN: $2456-8643$

Table - 5 Heat Stage Wise Calving Pattern

\begin{tabular}{|l|c|c|c|c|c|c|}
\hline Heat Stage & Abortion & Caesarian & Dystocia & $\begin{array}{c}\text { Minor } \\
\text { Assistance }\end{array}$ & Normal & $\begin{array}{c}\text { Grand } \\
\text { Total }\end{array}$ \\
\hline Early & 10 & 2 & 11 & 54 & 187 & \\
\hline & $(3.8 \%)$ & $(0.8 \%)$ & $(4.2 \%)$ & $(20.5 \%)$ & $(70.8 \%)$ & 264 \\
Mid & 376 & 16 & 138 & 1158 & & \\
\hline & $(5.1 \%)$ & $(0.2 \%)$ & $(1.9 \%)$ & $(15.8 \%)$ & $5623(76.9 \%)$ & 7311 \\
Late & 66 & 37 & 9 & 104 & 964 & \\
\hline Grand Total & $(5.6 \%)$ & $(3.1 \%)$ & $(0.8 \%)$ & $(8.8 \%)$ & $(81.7 \%)$ & 1180 \\
\hline
\end{tabular}

\section{In Year Wise Study of Calving Pattern}

Highest percentage of normal calving were observed in year 2011 (91.6\%) and lowest in year 2015 (47.8\%).Highest percentage of minor assistance was recorded in year $2015(42.8 \%)$ while lowest in year $2011(1.4 \%)$. Highest dystocia was recorded in year $2013(2.8 \%)$ and lowest in year $2011(0.7 \%)$. Highest abortion was recorded in year $2015(6.9 \%)$ and lowest in year 2013 $(3.8 \%)$.

Table - 6 Year Wise Calving Pattern

\begin{tabular}{|l|c|c|c|c|c|c|}
\hline Calving Year & Abortion & Caesarian & Dystocia & $\begin{array}{c}\text { Minor } \\
\text { Assistance }\end{array}$ & Normal & $\begin{array}{c}\text { Grand } \\
\text { Total }\end{array}$ \\
\hline & 73 & 2 & 8 & 17 & 1093 & \\
2011 & $(6.1 \%)$ & $(0.2 \%)$ & $(0.7 \%)$ & $(1.4 \%)$ & $(91.6 \%)$ & 1193 \\
\hline & 188 & 15 & 45 & 394 & 2507 & \\
2012 & $(6.0 \%)$ & $(0.5 \%)$ & $(1.4 \%)$ & $(12.5 \%)$ & $(79.6 \%)$ & 3149 \\
\hline & 112 & 35 & 82 & 514 & 2230 & \\
2013 & $(3.8 \%)$ & $(1.2 \%)$ & $(2.8 \%)$ & $(17.3 \%)$ & $(75.0 \%)$ & 2973 \\
\hline & 40 & 2 & 10 & 150 & 675 & \\
2014 & $(4.6 \%)$ & $(0.2 \%)$ & $(1.1 \%)$ & $(17.1 \%)$ & $(77.0 \%)$ & 877 \\
\hline & 39 & 1 & 13 & 241 & 269 & \\
2015 & $(6.9 \%)$ & $(0.2 \%)$ & $(2.3 \%)$ & $(42.8 \%)$ & $(47.8 \%)$ & 563 \\
\hline Grand Total & 452 & 55 & 158 & 1316 & 6774 & 8755 \\
\hline
\end{tabular}

\section{Season Wise Study of Calving Study}

Highest percentage of normal calving's were recorded in summer season (80.16\%) while lowest in rainy season $(74.95 \%)$. Highest percentage of minor assistance was recorded in rainy season $(17.29 \%)$. While lowest in summer season $(11.75 \%)$. Highest percentage of dystocia was recorded in summer season $(2.22 \%)$ while lowest percentage of dystocia was recorded in winter $(1.23 \%)$. Highest percentage of caesarean cases were recorded in winter season $(1.09 \%)$ while 
Vol. 5, No. 02; 2020

ISSN: $2456-8643$

lowest in rainy season $(0.28 \%)$. Highest percentage of abortions were recorded in rainy season $(5.52 \%)$ while lowest in winter season $(4.61 \%)$.

Table .7 Season Wise Calving Pattern

\begin{tabular}{|l|r|r|l|l|l|r|}
\hline $\begin{array}{l}\text { Row } \\
\text { Labels }\end{array}$ & Abortion & Caesarian & Dystocia & $\begin{array}{l}\text { Minor } \\
\text { Assistance }\end{array}$ & Normal & Grand Total \\
\hline Rainy & $160(5.52 \%$ & & & & & $2898(100 \%$ \\
\hline Summer & $157(5.36 \%$ & $15(0.28 \%)$ & $57(1.97 \%)$ & $501(17.29 \%)$ & $2172(74.95 \%)$ & $2928(100 \%$ \\
\hline Winter & $135(4.61 \%$ & $32(1.09 \%$ & $65(2.22 \%)$ & $344(11.75 \%)$ & $2347(80.16 \%)$ & $2929(100 \%$ \\
\hline $\begin{array}{l}\text { Grand } \\
\text { Total }\end{array}$ & $452(5.16 \%$ & $55(0.63 \%$ & $158(1.80 \%$ & $1316(15.03 \%$ & & \\
)
\end{tabular}

\section{Calf Sex Wise Study of Calving Pattern}

Highest percentage of normal calving were observed in female calf born (82.3\%) and while in male calves born it was $(81.3 \%)$. Highest percentage of minor assistance was recorded in male calves born (16.6\%) while in it was $(15.2 \%)$ in female calf born study. Highest percentage of dystocia were recorded in female calves born $(1.9 \%)$ while it was $(1.5 \%)$ in male calves born. Percentage of abortion were $(0.61 \%)$ in male calves and $(0.63 \%)$ in female calves born case.

Table .8 Calf Sex Wise Calving Pattern

\begin{tabular}{|c|c|c|c|c|c|}
\hline Sex of Calf & Caesarean & Dystocia & $\begin{array}{c}\text { Minor } \\
\text { Assistance }\end{array}$ & Normal & $\begin{array}{c}\text { Grand } \\
\text { Total }\end{array}$ \\
\hline Male Calf & $26(0.61 \%)$ & $66(1.5 \%)$ & $706(16.6 \%)$ & $3463(81.3 \%)$ & 4269 \\
\hline Female Calf & $25(0.63 \%)$ & $75(1.9 \%)$ & $599(15.2 \%)$ & $3240(82.3 \%)$ & 3949 \\
\hline
\end{tabular}

\section{Study of Retention of Placenta}

In retention of placenta study overall $32.48 \%$ (2844) cases show retention of placenta while in Central plain of Uttar Pradesh it was 22.54\% in Mid -Western plain of Uttar Pradesh $36.28 \%$ and in Western plain zone of Uttar Pradesh73.48\%. In parity wise study of retention of placenta were highest in third parity $39.38 \%$ while lowest in first parity $26.40 \%$ while in heifer it was $33.03 \%$.

\section{DISCUSSION}

The number of calves born in the present study was 8755 . Outof this 4269 was male and the rest 3949 were female and the ratio (male: female) was 52:48. Our findings are in agreement with the findings of Tesfu et al. (2014) who reported sexratio of 52:48 in dairy farms subjected to artificial insemination. In present study, the overall incidence of retained placenta was higher than reported by Pandeet al. (2014) and Gupta et al. (1999) in buffaloes. This variation in the incidence of RFM may be attributed to variations in predisposing factors to which the animals 
Vol. 5, No. 02; 2020

ISSN: 2456-8643

are subjected to among which include nutritional status and management. Higher incidence of retained placenta was recorded in dams with male fetuses than with female fetus. Our finding are in agreement with that of Erb et al. (1958) who reported 56\% cases of retained placenta associated with birth of male calves. Moreover, retained placenta in cattle isalso associated with dystocia, abortion, short or long gestation and twinning (Bhattacharyyn et al., 2009) which also are important predisposing factor for occurrence of RFM. The reported incidence of dystocia varies widely between $2-11 \%$ (Roberts, 1984). Our study reports incidence of $1.80 \%$ which is in agreement with the findings of Sekhar and Rajani(2014) who reported 2.9\% prevalence of dystokia among cross bred cows of Chittoor District of Andhra Pradesh. High incidence of dystokia was observed with female calves which might be attributable to their higher birth weight (Patil et al.,2014). The Higher occurrence of dystokia in rainy and summer season than winter in the present study may be attributed to higher number of calvings occurring in these season. The incidence of abortion $(5.16 \%)$ recorded in this study is similar to the findings reported earlier by Shiferaw et al. (2003) and Kassahun (2003). This finding was also similar with the findings of Sekhar and Rajani (2014) whohave reported prevalence of $6.7 \%$ in dairy farms and at farmers in Andhra Pradesh. Satya pal (2003) reported the incidence of abortion in Karan Fries cows was significantly affected by parity, season and period and the incidence was lower during winter and it is higher during second and third lactation. In this study, incidence of dystocia was significantly affected byparity and it was higher during first lactation. Omar et al. (1975) reported that season hadno significant effect on abnormal calving. On the contrary, Singh (1979) observed seasonal variation in the incidence of abnormal calving being high in hot dry and hot humid seasons. About parity it had non-significant effect on calving abnormalities(Prabhu and Chatterjee, 1970; Sharma and Jain,1982), however, few workers (Tomar et al., 1975;Kaikini et al., 1976) did mention a significant effect. Most of the workers (Singh, 1979; Vaccaro and Vaccaro, 1981; Mukherjee et al., 1993; Satya pal,2003) documented significant effect of season oncalving abnormalities and very few (Tomar et al.,1975) reported non-significant effect.

\section{CONCLUSION}

The outcome of this study strongly suggest that Agro climatic Zone viz. Parity, body condition, season of calving, calf sex and retention of placenta study all these factors should be taken into consideration during calving pattern study. Greater awareness about seasonal predisposition of certain disorders may draw attention towards a proactive approach for better management.

\section{Aknowledgments}

The authors are thankful to President, Senior Vice President, Management team of BAIF Development Research Foundation and all stakeholders in study area those who participated and cooperated during study

\section{REFERENCES}

Bhattacharyyn HK, Fazali MR, Buch BA. Retained foetalmembrane in cows of Kashmir valley: prevalence andmanagement. Haryana Veterinarian. 2009; 48:14-16. 
Vol. 5, No. 02; 2020

ISSN: $2456-8643$

Erb RE, Hinze PM, Gildow EM, Morrison RA. Retainedfetal membranes- the effect on dairy cattle. Journal of American Veterinary Medicine Association. 1958;133:489-496.

Kassahun M. Major clinical reproductive problems ofsmallholder dairy cows in and around Awassa. DVMthesis. Faculty of Veterinary Medicine, Addis AbabaUniversity, Debre Zeit, Ethiopia, 2003.

Kaikini, A. S. et al. (1976). Studies on the incidence of normal and pathological termination of pregnancies in dairyanimals. Indian J. Anim. Sci., 46: 19.

Mukherjee, K. et al (1993). Factors affecting reproduction disorders and their association in Karan Fries herd. IndianVet. J., 70(2): 121-124.

Pande N, Agrawal RG, Agrawal R, Shrivasatava OP, JainSK. Prevalance of periparturient reproductive disordersand calving pattern in buffaloes. Intas Polivet. 2014;15(2):205-207.

Patil AS, Rathod R, Nagaraja BN. Retrospective studieson occurrence of dystocia and its management indomestic animals. Intas Polivet. 2014; 15(2):269-276.

Prabhu, S. S. and Chaterjee, S. N. (1970). Incidence of abortion in Indian cattle. Indian J. Anim. Sci., 40: 266.

Roberts, S. J. (1971). Veterinary Obstetrics and Genital Disease (Theriogenology) 2nd edition. Indian ed. scientific bookagency, Calcutta-1.

Roberts SJ. Veterinary Obstetrics and Genital Diseases(Theriogenology). 3rd ed. CBS Publishers andDistributors, New Delhi, India, 1986.

Satya pal, 2003. Investigation on health disorders in dairy cattle and buffaloes during pre and post partum period.Ph.D thesis submitted to NDRI, Karnal

Sekhar CC, Rajani N. prepartum and postpartumreproductive problems in bovines- A retrospective studyreproductive problems in bovines- A retrospective studyof 711 cows. Intas Polivet. 2014; 15(2):199-204.

Sharma, K. N. S., Jain, D. K. (1982). Genetic and nongenetic factors affecting prenatal mortality in bovines. IndianJ. Dairy Sci., 53(8): 799-802.

Shiferaw Y, Bekena M, Tenhagen BA, KassaT. Reproductive performance of crossbred dairy cows indifferent production systems in the central highlands ofEthiopia. Tropical Animal Health Production. 2003;35(6):551-561

Singh, R. N. (1979). Influence of breed groups (Zebu X Exotic) on health, production and breeding efficiency. Ph.DThesis. NDRI, Karnal.

Tesfu T, Gebrekidan B, Afera B. Assessment andcomparision of sex ratio following artificial inseminationand natural mating in small scale and modern dairy farmsin mekelle. Journal of reproduction and infertility. 2014;5(20):58-64.

Tomar, S. S. et al. (1975). Genetic and non-genetic variations in prenatal calf losses. Indian J. Dairy Sci., 45: 533

Vaccaro, R. and Vaccaro, L. D. (1981). . Age at first calving and reproductive traits in daughters of Brown Swiss andFriesian bulls. Anim. Breed Abstr., 52: 6555. 